\title{
THE RELATIONSHIP BETWEEN ORGANIZATIONAL CULTURE, MANAGEMENT INNOVATION, PRODUCT INNOVATION, AND NEW PRODUCT MARKET PERFORMANCE
}

\author{
*Cemal ZEHIR \\ *Dilek KARACA \\ **Dogan BASAR \\ * Yıldız Technical University, Turkey \\ **Bolu Abant Izzet Baysal University, Turkey
}

\begin{abstract}
The aim of this research is to examine the relationship between organizational culture, management innovation, product innovation and new product development performances. The data were collected through questionnaires on the production operations in Istanbul. The study first provides literature knowledge about organizational culture, management innovation, product innovation and new product development performance. In this context, research model and related hypotheses have been developed. In order to test the research hypotheses, a total of 594 managers of the 141 manufacturing companies operating in the manufacturing sector in Istanbul were used the data obtained by the questionnaire method. Data collected from 594 executives were analysed using SPSS software program. As a result of this study, it has been determined that product innovation has intermediary effects mediating on organizational culture dimensions and new product development performance. These empirical findings show that in the manufacturing sector, competitive advantage can be achieved through the development of businesses (in terms of organizational culture, management innovation and new product development performance relevance).
\end{abstract}

Keywords: Organizational Culture, Management Innovation, Product Innovation, New Product Development Performance.

\section{INTRODUCTION}

Increasing global competition has made it imperative for organizations to keep up with innovations such as new product development, innovation, and the creation of an organization culture that will embrace these insights. In this rapidly changing global competitive environment, organizations need to create a culture that gives them a distinctive character in order to survive. Each organization has its own cultural understanding and organizational culture plays an important role in organizations' development of competitive advantage.

There are many factors that affect organizational culture. Organizations such as business practices, management practices, product development characteristics, moral factors, decision-making styles that characterize the society and industry in which it operates act on the whole of beliefs, values and assumptions. Through interaction with these factors, the organization creates its own culture. When assessed in the context of these factors, it is worth investigating the relationship between organizational culture, management innovation, product innovation and new product development performance.

Changing environmental conditions and technology make difficult of adaptation of organizations. An organization is innovating in ways to increase the rate of its change. Organizations need to increase management innovation capacity and new product development performance in line with customer expectations so that they can exist and survive in the long run.

In this study, the relationship between management innovation, product innovation and new product development performance is discussed as four dimensions of organizational culture. As regards organizational culture, management innovation and new product development performance have been examined. Recently developed scales related to organizational culture, new product development, product 
Journal of Global Strategic Management | V. 12 | N. 2 | 2018-December| isma.info | 027-036 | DOI: 10.20460/JGSM.2019.266 innovation and management innovation have been used. Therefore, the study is expected to contribute to the progress of science in management and the development of competitive directions of the organisations in Turkey by evaluating the cultural components effectively.

\section{LITERATURE REVIEW AND THEORETICAL FRAMEWORK Organizational Culture}

The definition of culture first emerged when anthologists began to examine the differences between humans and animals in order to distinguish social sciences from science. In this context, definitions focus on the characteristics of human and human communities. When we examine the definitions of the first culture, the culture with the simplest form; is defined as a complex whole of knowledge, belief, art, morality, law, etc. that a person is given as a part of a community( Hatch ve Cunliffe, 2006).

With the spread of cultural studies around the world over time, societies began to be associated with different human societies and different societies were tried to compare with each other. These studies on the effects of culture on communities have laid the foundation for the concept of organizational culture because it is a community in organizations. Researching human and group behavior in organizations with the approach of human relations forms the basis for the concept of organizational culture (Unutkan, 1995, p. 35). For the first time, Elliot Jaques conceptualized organizational culture in 1951 with the Book of Changing Culture of a Fabric, but the organization did not focus on its components such as value, norm, and belief (Hatch ve Cunliffe, 2006). The interpretive paradigm is that the organization does not consider the culture as a means to improve organizational outcomes, while the classical organizational approach and modern organizational approaches assume that culture is objectively addressed and rationally constructed to improve efficiency and productivity in organizations. The organization sees the culture as the building block of the instincts of social co-movement and examines how individuals and groups interpret social events in the organization (Keating, 2008, p. 42). The evaluation of the organizations with different paradigms that have been developed, which is if the concept of organizational culture related to the organization, is evaluated differently.

According to Edgar Schein (2010, p. 6), 'organizational culture' is the basic approach to external integration and internal integration that is necessary for an organization to work effectively and accepted by new members. Schein considers this definition to be a conservative tool for the organizational members against the outside environment of the organization.

According to Harrison Trice and Jenice Beyer (1992, p. 2)' on the one hand, organizational culture is 'a network of meaning that includes values, norms and ideologies in the organization'.

The common point of these definitions is constituted of beliefs, attitudes, understandings, norms and values.

Organizational culture according to Hofstede who is investigating the cultural differences of societies on the other hand; it is considered as a subset of wider upper cultures (Hofstede, 1980).

According to Deal and Kennedy, organizational culture is; developed values, beliefs, norms and symbols that convey to the environment of the organization. At the same time, Deal and Kennedy explored the relationship between organizational culture and environment and created four different forms of culture for organizations. These types of organizational culture emerged in the face of the situation of the region in which the organization operates; environmental uncertainty is high, when decisions are risky, hard male macho culture is low, when risk is low, feedback is fast in the environment, plays hard in the environment, raises the environmental awareness of the company in a long period of high feedback culture, process culture is emerging when the feed back is slow (Deal ve Kennedy, 1982, p. 107-109).

There are different types of culture in the literature, but this study focuses on the types of organizational culture that Quin and Cameron have developed by considering environmental impacts (Harrison and Stokes, 1992; Quin and Cameron, 1999; Goffee and Jones, 1998; Kotter and Hoskett, 1992). Quinn and Cameron's dynamism and stability at the opposite extremities of an axis in the organizational culture model and the extremities of the other axis that interrupts it are the dimensions of internal and external orientation.

Four different organizational cultures, which are the intersection of these axes; 
Journal of Global Strategic Management | V. 12 | N. 2 | 2018-December| isma.info | 027-036 | DOI: 10.20460/JGSM.2019.266

Hierarchy Culture is assessed as an understanding of how centrality is active in high, authoritarian control processes and focuses on intra-organizational functions (Öztop, 2008, p. 36).

Market Culture refers to an environment of an organizational environment that is dominated by an external environment and competitive at the same time (Erdem, 2007, p. 66).

Clan Culture refers to a more flexible environment for organizations, which is the frontrunner of organizational commitment, has the spirit of intra-organizational unity and cooperation, supports informal relationships, is far from being competitive (Erdem, 2007, p. 66).

Adhocracy culture, in its relations with the external environment, promotes dynamic, out-of-the-box information organization structures that work well and have good adaptation mechanisms. It promotes innovation in intra-organizational relationships and expresses organizational environments that encourage employees to take risks and adopt a creative understanding (İşcan ve Timuroğlu, 2007, p. 123).

\section{New Product Development}

Rapidly changing environmental conditions and technological developments have left many strategies out of competition. In recent years, organizations that are trying to gain advantage in a highly competitive environment place great emphasis on mastering new product development (Yang and Yu, 2002, p. 219). New product development is regarded as a long and risk-filled process that has introduced to create new products. The variable is heavily influenced by external and internal environmental conditions (Sanders and Monrodt, 1994, p. 98).

A number of factors are examined as new product development processes or factors in Literature. Rosenau and Moran (1993) argued that new product development could be carried out successfully by using management tools such as quality management, cross-functional teamwork, and market change speed. On the other hand, Bowen et al. (1994) stated that there are seven critical factors that can influence the development of new products. These;

- Evaluation of the project as a whole with the understanding of the system approach,

- Ability to correct the learning speed and error of the firm,

- The amount of the responsibility to be imposed on the teams,

- The amount of the inoculation of the proprietorship and the strength of the company,

- The company's leadership and the structure of the organization

- The capacity of its performance to make forward breakthroughs and,

- Finally, the use of the company's core competencies.

Cooper and Kleinschmidt (1995) state that; high quality new product process, open and well communicated new product strategy, sufficient resources for new products, top management's commitment to new products, entrepreneurial climate for product innovation, senior management responsibility,strategic focus and synergy for high-quality development teams and cross-functional teams.

In another research, Bobrow (1997) presented a list of achievements in developing new products. Bobrow suggested that the strategic orientation, the nature of the organization culture behind the company's new product development, the sensitivity of human and physical resources usage and the quality of the teams to be built to develop new products would directly affect the success of developing new products.

There are different opinions on the factors mentioned above and other sources that are effective in developing new products.

\section{Management Innovation}

Innovation aims not to find the undiscovered but to discover the processes of creating value. Innovation is considered as an activity with continuity. It is clear that the competitive advantage of a single innovation is not at all risky and unsustainable, given the speed of the developing technology in the last century, the change of customer expectations, and the speed with which competitors who easily access technology and technology can imitate innovation. For this reason, the company has to be identified with the culture by becoming a continuous activity of innovation (K1r1m, 2007, p. 5).

Micro and macro-scale economic actors who want to gain more competitive advantage and superiority and who want to be in more active and productive production will have the opportunity to achieve their targets at the time they can fit into the economic culture systems of innovation (Tüsiad, 2003). 
Journal of Global Strategic Management | V. 12 | N. 2 | 2018-December| isma.info | 027-036 | DOI: 10.20460/JGSM.2019.266 Innovation is simply defined as a new product, service or business style that gives an organization a competitive advantage (İnan, 2009, p. 15). Innovation can be done in an enterprise's products, services, management procedures, production distribution methods, design and marketing methods. These are called Product Innovation, Service Innovation, Process Innovation, Organizational Innovation, Management Innovation, and Marketing Innovation, respectively (Elçi, 2007, p. 15).

Geoffrey Moore has divided innovation into eight genres. These are order disruptive strategic innovation, application innovation, new product innovation, process innovation, experience innovation, marketing innovation, business model innovation and structural innovations (Kırım, 2007, p. 14).

In this research, management innovation and product innovation are discussed in relation to research hypotheses and variables.

Management innovation involves organizational processes with management processes. At the same time, the organization is indirectly connected with basic business activities. There may be many changes in management innovation, organizational core business models, strategy, leadership styles, or organizational culture. The use of total quality management systems in enterprises is a good example of management innovation (Paul, 2008, p. 16).

Management innovation in Gary Hamel's 2008 management innovation process is described in detail as: Management innovation; is the most developed and end-to-end management approach to management practice, processes, organization and technology, and its management approach to further organizational goals (Hamel, 2008, p. 825).

Innovating in management is defined as the development of new products individually, groupwise and organizationally, the management adaptation of new services and applications (Walker, Damanpour, 2010, p.369). Management innovation is an innovation type that aims at increasing the efficiency of managerial processes while at the same time predicting demands for the development of new products and services (Nieves, 2015, p. 58).

The factors that determine management innovation are as follows; self-managing teams, management practices, management processes and organizational structure. In order for management innovation to take place, creativity and innovations need to be applied or adapted in relation to these factors.

At the same time, management innovation has considerable precaution as being the type of innovation that will carry out the innovation that will create a favourable environment for all the different innovations in the organization.

\section{Product Innovation}

Product innovation is defined as a change made in a knitwear product. Developing an existing product and taking it to the next level is called product innovation (Yao ve Wang, 2008, p 906).

Generally speaking, product innovation; is to improve the existing features of the company's products largely to meet customer demand and demand. Any changes made to the functional specification of the product that will provide ease of use, in its technical specifications and components, are defined as the content of the product innovation (Arslan, 2012, p. 36).

In product innovation, if the firm intends to increase the performance of the existing product, then the customer must successfully interpret the expectations of the customer in order to pay extra for this new performance (Kırım, 2007, p. 9).

In general, firms use the demand power of the market and the pulling power of technology to improve product innovation capabilities. As a type of innovation is antagonistic that important for companies to gain competitive advantage. At the same time, the core competencies of the business stand out for successful product innovations (Leonard, Barton, 1992).

It is worth noting that the creation and research of all these innovations and cultures that support the changes are also examined.

H1: Organizational culture dimensions affect new product market performance positively

H2: Organizational culture dimensions affects management innovation positively

H3: Management innovation affect new product market performance positively

H4: Organizational culture dimensions affects product innovation positively 
H6: Organizational culture dimensions positively affect new product market performance through product innovation

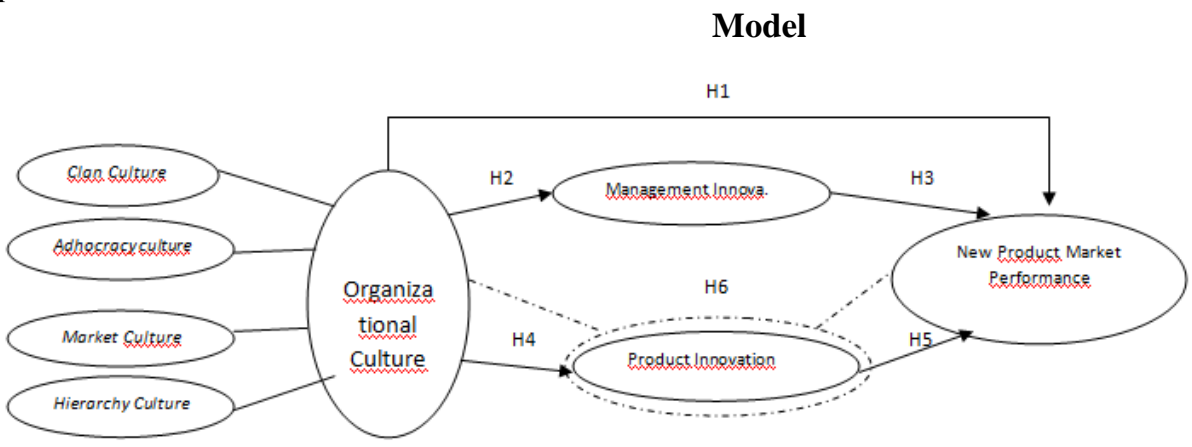

Figure 1. Research Model

\section{RESEARCH METHOD}

\section{Sample and Data Collection}

This study is designed to investigate the relationship between organizational culture, management innovation and new product development performance of manufacturing industry enterprises in Istanbul. The data of the study were obtained by questionnaires collected from a total of 594 middle and upper level managers of 141 enterprises operating in the manufacturing sector in Istanbul between 2016-2018. All dimensions and relationships of the study were measured with a total of 47 questioned likert type scales available in the literature.

Table 1. Sample Demographics

\begin{tabular}{|c|c|c|c|c|c|}
\hline Firm Operation Field & Frequency & Valid Percent & Sub Sectors & Frequency & Valid Percent \\
\hline Local & 13 & $9,4 \%$ & Food & 10 & $7,1 \%$ \\
\hline National & 28 & $20,1 \%$ & Wood / Paper & 4 & $2,9 \%$ \\
\hline Global & 98 & $70,5 \%$ & Medicine / Medical & 9 & $6,4 \%$ \\
\hline Firm Size & Frequency & Valid Percent & Textiles & 8 & $5,7 \%$ \\
\hline $0-249$ & 33 & $23,1 \%$ & Machine & 9 & $6,4 \%$ \\
\hline $250-500$ & 23 & $16,3 \%$ & Automotive & 16 & $11,4 \%$ \\
\hline 501-1501 & 27 & $19,2 \%$ & Furniture & 2 & $1,4 \%$ \\
\hline $1500+$ & 58 & $41,3 \%$ & Chemical & 8 & $5,7 \%$ \\
\hline Firm Age & Frequency & Valid Percent & Main Metal & 8 & $5,7 \%$ \\
\hline below 10 & 7 & $5,0 \%$ & Electric Machines & 7 & $5,0 \%$ \\
\hline $10-25$ & 34 & $24,1 \%$ & On Stone and Soil & 2 & $1,4 \%$ \\
\hline $25-50$ & 63 & $44,7 \%$ & Other production & 57 & $40,7 \%$ \\
\hline above 50 & 37 & $26,2 \%$ & Total & 141 & 100,00 \\
\hline
\end{tabular}

Analyses

Quincy and Cameron's (1999) measure Vaccaro, Jansen, Bosch and Volberda (2012) scale for organizational culture type scale, management innovation and product innovation, Abdulkareem Awwad (2016) for new product market performance, are used.

The questions 1, 6 and 7 of the adhocracy culture questionnaire, the 6th question of the market culture questionnaire and the 1st question of the management innovation questionnaire were removed from the analysis because the factor loads were low.

\section{Factor Analysis, Reliabilities and Correlations}

Factor analysis was used to determine the sub-dimensions of the scales used in the research and to examine the construct validity of the scales. The best fit of the data was obtained by promax rotation and principal component analysis. Kaiser-Meyer Olkin (KMO) sample productivity test and Bartlett test were applied in order to test the suitability of the data set for factor analysis. As a result of the analysis, it is seen that the KMO value is 0.935 and that the sigma value of the Bartless test is smaller than 0.05, so that it is proved that the total data set is suitable for factor analysis and that significant factors can be obtained 
Journal of Global Strategic Management | V. 12 | N. 2 | 2018-December| isma.info | 027-036 | DOI: 10.20460/JGSM.2019.266 from the research data. In the main component analyzes, the lower limit of the factor weights of each material, taking into account the sample size, was taken as 0.45 (Hair, Black, \& Babin, 2010, p. 120).

According to the PCA, each variance was attributed to the predicted factor component and the factor weights ranged from 0.525 to 0.862 . Moreover, weight factors were observed mainly on the value of 0.500. There are twenty-two items for organizational culture, five for management innovation, seven for new product performance and eight for product innovation. The results of the factor analysis are shown in Table 2.

Table 2. Factor Analysis

\begin{tabular}{|c|c|c|c|c|c|c|c|c|}
\hline \multirow{2}{*}{ Factors } & \multirow{2}{*}{ Items } & \multicolumn{7}{|c|}{ Factor Loadings } \\
\hline & & F1 & F2 & F3 & F4 & F5 & F6 & F7 \\
\hline \multirow{6}{*}{ 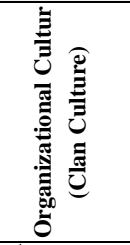 } & OC_clan_1_mean &, 747 & & & & & & \\
\hline & OC_clan_2_mean & 862 & & & & & & \\
\hline & OC_clan_3_mean &, 836 & & & & & & \\
\hline & OC_clan_4_mean & 850 & & & & & & \\
\hline & OC_clan_5_mean & 824 & & & & & & \\
\hline & OC_clan_6_mean &, 746 & & & & & & \\
\hline \multirow{4}{*}{ 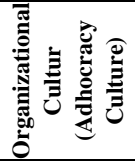 } & OC_adhocracy_2_mean & & ,618 & & & & & \\
\hline & OC_adhocracy_3_mean & &, 711 & & & & & \\
\hline & OC_adhocracy_4_mean & & ,611 & & & & & \\
\hline & OC_adhocracy_5_mean & &, 551 & & & & & \\
\hline \multirow{5}{*}{ 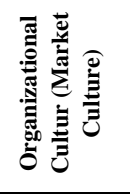 } & OC_market_1_mean & & &, 750 & & & & \\
\hline & OC_market_2_mean & & &, 525 & & & & \\
\hline & OC_market_3_mean & & &, 705 & & & & \\
\hline & OC_market_4_mean & & & ,634 & & & & \\
\hline & OC_market_5_mean & & &, 702 & & & & \\
\hline \multirow{7}{*}{ 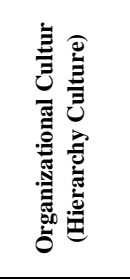 } & OC_hiera_1_mean & & & &, 752 & & & \\
\hline & OC_hierarchy_2_mean & & & & ,649 & & & \\
\hline & OC_hierarchy_3_mean & & & & ,661 & & & \\
\hline & OC_hierarchy_4_mean & & & & ,672 & & & \\
\hline & OC_hierarchy_5_mean & & & &, 599 & & & \\
\hline & OC_hierarchy_6_mean & & & &, 542 & & & \\
\hline & OC_hierarchy_7_mean & & & &, 716 & & & \\
\hline \multirow{8}{*}{ 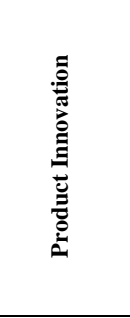 } & pro_ser_innov_1_mean & & & & & ,703 & & \\
\hline & pro_ser_innov_2_mean & & & & & ,734 & & \\
\hline & pro_ser_innov_3_mean & & & & & ,738 & & \\
\hline & pro_ser_innov_4_mean & & & & &, 772 & & \\
\hline & pro_ser_innov_5_mean & & & & & 673 & & \\
\hline & pro_ser_innov_6_mean & & & & & ,714 & & \\
\hline & pro_ser_innov_7_mean & & & & &, 732 & & \\
\hline & pro_ser_innov_8_mean & & & & &, 567 & & \\
\hline \multirow{7}{*}{ 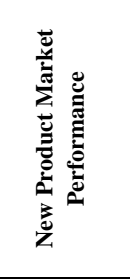 } & n_pro_mrk_perf_1_mean & & & & & & ,764 & \\
\hline & n_pro_mrk_perf_2_mean & & & & & & 805 & \\
\hline & n_pro_mrk_perf_3_mean & & & & & &, 849 & \\
\hline & n_pro_mrk_perf_4_mean & & & & & & 844 & \\
\hline & n_pro_mrk_perf_5_mean & & & & & &, 800 & \\
\hline & n_pro_mrk_perf_6_mean & & & & & & 851 & \\
\hline & n_pro_mrk_perf_7_mean & & & & & & ,836 & \\
\hline \multirow{5}{*}{ 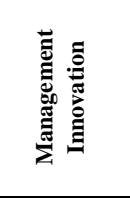 } & manag_innov_2_mean & & & & & & & 850 \\
\hline & manag_innov_3_mean & & & & & & &, 780 \\
\hline & manag_innov_4_mean & & & & & & & ,773 \\
\hline & manag_innov_5_mean & & & & & & & ,766 \\
\hline & manag_innov_6_mean & & & & & & & 801 \\
\hline & Explained Varience (\%) & 21,616 & 8,526 & 7,114 & 4,202 & 3,354 & 2,753 & 2,168 \\
\hline & Total Explained Varience (\%) & \multicolumn{7}{|c|}{51,466} \\
\hline
\end{tabular}


Journal of Global Strategic Management | V. 12 | N. 2 | 2018-December| isma.info | 027-036 | DOI: 10.20460/JGSM.2019.266 Cronbach's Alpha value was used in evaluating factor reliability (Table 3). On the basis of the Cronbach's alpha values of the factors, factor reliability was observed to be above the acceptable lowest value of 0.70 (Hair et al., 2010). This also indicates that these factors have internal consistency and reliability.

Table 3. Correlations, Means and Standard Deviations

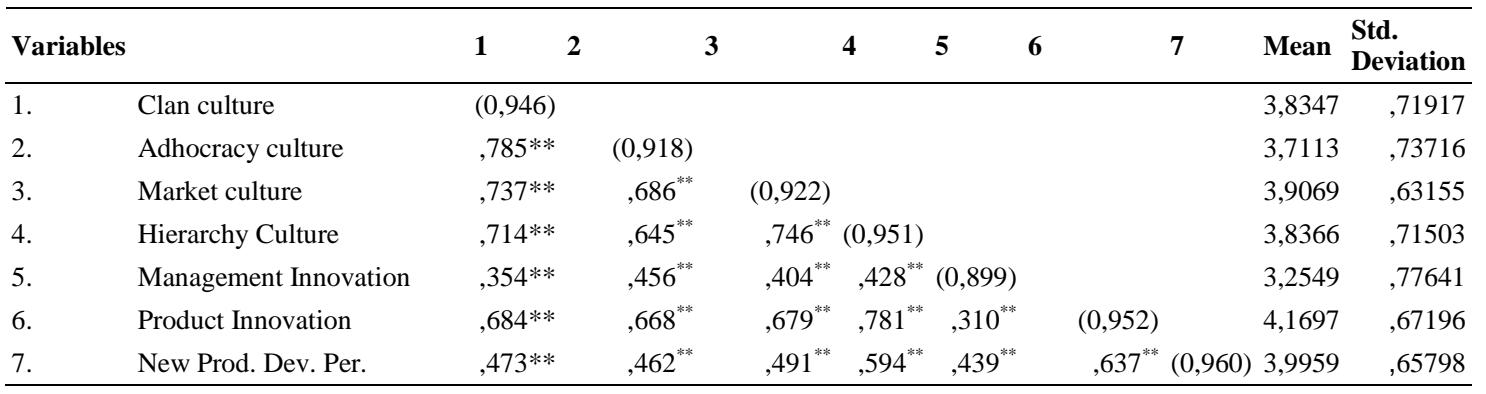

**; Correlation is significant at the 0.01 level. *. Correlation is significant at the 0.05 level. Cronbach's Alpha values are represented in diagonals

\section{FINDINGS}

We used multiple regression analysis to test hypotheses. Table 4 shows the results of the regression analysis. The conclusion of the regression analysis in Model 1 shows that there is a significant effect of hierarchical cultures $(\beta=477 \mathrm{p}<0.001)$ on organizational dimensions in new product development performance. Clan culture and market culture have no significant impact on new product development performance. Hl Organizational culture dimensions affect new product market performance positively was disclosed at $60 \%$. As a result of these findings, our hypothesis was accepted at the level of significance of $0.1 \%$.

Model 2 shows that from organizational culture dimensions, adhocracy culture $(\beta=0.382, p<0.001)$ and hierarchy culture $(\beta=0.245, p<0.001)$ have significant effects on management innovation. Market and clan cultures have no significant impact on management innovation. Thus, H2: Organizational culture dimensions affects management innovation positively is partially supported. The model's disclosure percentage is $50 \%$, which indicates that the organizational culture management innovation level is lower than the disclosure level for new product development performance.

In Model 3, management innovation $(\beta=0.439, \mathrm{p}<0.001)$ has a significant impact on new product development performance and therefore is H3: Management innovation affect new product market performance positively supported. The percentage of disclosure of the model is $43 \%$.

In Model 4, from organizational culture dimensions hierarchy culture has a significant effect on product innovation $(\beta=0.524, \mathrm{p}<0.001)$. Clan culture and market culture did not have a significant effect on product innovation. The model is disclosed at $80 \%$. Therefore, is H4: Organizational culture dimensions affects product innovation positively supported.

Product innovation in Model $5(\beta=0.637, \mathrm{p}<0.001)$ has a significant impact on new product market performance. H5:Product innovation affects new product market performance supported. The model's disclosure percentage is $63 \%$.

Model 6 has been designed to investigate the instrumental impact of product innovation (Baron and Kenny, 1986) on the relationship between organizational culture dimensions and new product market performance. We see that the effects of organizational culture dimensions on the new product market performance in Model 1 have changed in Model 6. H6: Organizational culture dimensions positively affect new product market performance through product innovation supported. The model's disclosure percentage is $65 \%$. The influence of the adhocracy culture is entirely absent, and the influence of the market culture is diminishing when the mediator variable, product innovation, is included in the model. $\mathrm{H} 4$ is therefore partly supported. According to the results, product innovation is the partial mediator variable in this research. 
Table 4. Regression analyses for hypotheses testing

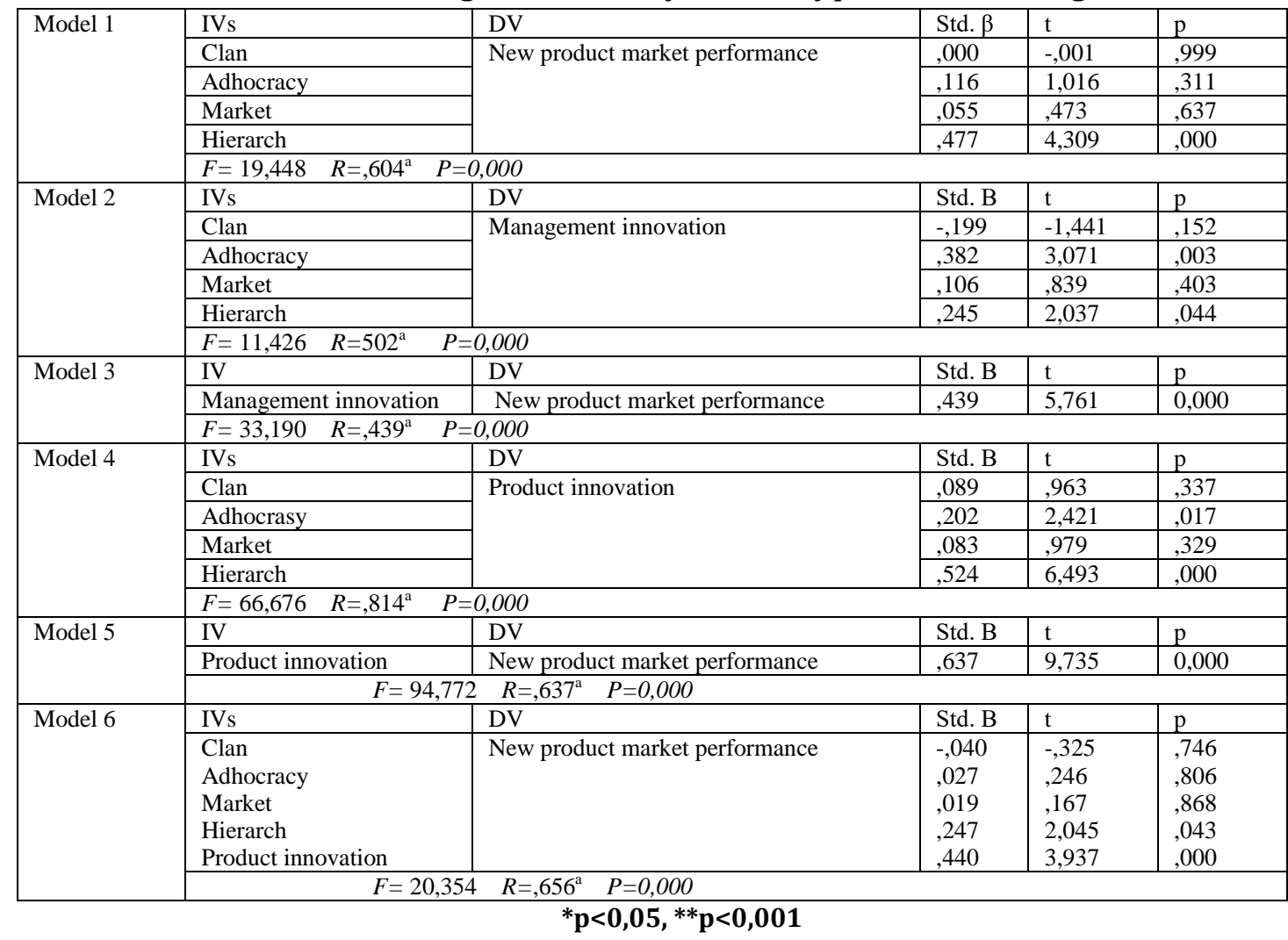

\section{CONCLUSION AND DISCUSSIONS}

This study was based on the theoretical foundations that existed in previous studies. The main aim in this research is to investigate the interdependent management innovation between organizational culture and new product development performance and the mediating variable role of product innovation. Increasing competition in the organizational sense and organizations' survival prove the necessity of adopting different management styles and understandings. This situation makes researching important at the same time. Because the findings of this research can provide organizations that operate in the manufacturing sector to perform better in this competitive business environment.

The results of the analysis related to the research can be explained as follows. Organizational culture dimensions are affecting new product development performance positively. Clan culture and market cultures do not have any influence new product development performance. This may require deeper research. Organizational culture dimensions are observed to have a positive influence on management innovation and product innovation. This finding may allow organizations to adopt a culture that will strengthen their new product development performance. At the same time, organizations can increase their competitive advantage by improving their skills. In addition, according to the findings hierarchical culture from organizational culture dimensions has pretty much impact on new product development performance compared to the other dimensions. Adhocracy culture has also been observed to influence management innovation positively.

As a result of these findings, it is believed that organizational culture dimensions will help organizations improve the performance of new product development through product innovation, improve organizational performance and indirectly maintain organization sustainability, and it is argued that the findings are guiding the managers in this respect.

There are a few limitations to this research. As the first limitation of the study, it can be said that only the evaluation of the new product market performance of the business can be considered. Financial performance has been ignored. In addition, performance indicator information was measured by subjective opinions only in the questionnaire. For further research, we can measure more performance indicators such as the analysis of business balances. For future studies, organizational culture and other parameters that will mediate new product development performance can be sought. 


\section{REFERENCES}

Abdulkareem Awwad Dr. Mamoun N. Akroush , (2016). "New Product Development Performance Success Measures: An Exploratory Research", EuroMed Journal of Business, Vol. 11 Iss 1

Baker WE, Sinkula JM.( 1999). The Synergistic Effect Of Market Orientation And Learning Orientation On Organizational Performance. J Acad Mark Sci;27: 411 -427.

Baron, R. M., \& Kenny, D. A. (1986). The Moderator-Mediator Variable Distinction In Social Psychological Research: Conceptual, Strategic, And Statistical Considerations. Journal Of Personality And Social Psychology, 51(6), 1173.

Bobrow, E. E. (1997). The Complete Idiot's Guide to New Product Development, Macmillan, New York.

Bowen, H. K., Clark, K. B., Holloway, C. A. and H. Kent (1994). The Perpetual Enterprise Machine: Seven Keys to Corporate Renewal Through Successful Product and Process Development, Oxford University Press, New York.

Cameron, K. S. and Quinn, R. D. (1999). Diagnosing And Changing Organizational Culture, Massachusetts: Addison-Wesley Publishing Company Inc.

Deal, T. E., Kennedy, A. A., (1982). Corporate Cultures: The Rites And Rituels of Corporate Life: Addison-Wesley Publishing Co.

Edgar H. Schein. (1993). 'On Dialogue, Culture And Organizational Learning', Organizational Dynamics, Vol. 22, No. 2:40-51

Elif Turkan Arslan, (2012). İnovasyon İle İç Girişimcilik Etkileşimi: Bilişim 500 Şirketlerinde Bir Uygulama, Doktora Tezi,İsparta,Turkey

Erdem Ramazan; (2007). “Örgüt Kültürü Tipleri İle Örgütsel Bağlılık Arasındaki İlişki”, Eskişehir Osmangazi Üniversitesi IIIBF Dergisi, 2(2): 63-79.

Erdem, R. (2007). “Örgüt Kültürü Tipleri ile Örgütsel Bağlılık Arasındaki İlişki: Elazığ İl Merkezindeki Hastaneler Üzerinde Bir Çalışma”. Eskişehir Osmangazi Üniversitesi İ̈BF Dergisi, 2(2), 63-79

Gary Hamel, Julian Birkinshaw. (2008). ‘ Management Inovation', Academy of Management Review ,Vol.33, No.4. 825-845

Hair, J. F., Black, W. C., Babin, B. J., \& Anderson, R. E. (2010). Multivariate Data Analysis: A Global Perspective. 7th edn. Pearson Prentice Hall Publishing, Upper Saddle River.

Hofstede, G., (1980). Culture's Consequences: International Differences in Work-related Values. Beverly Hills: Sage

Holt, J.L. and DeVore, C.J. (2005). "Culture, Gender, Organizational Role, and Styles of Conflict Resolution: A Meta-Analysis”, International Journal of Intercultural Relations, 29: 165-196.

Ignacio G. Vaccaro, Justin J.P. Jansen, Frank A.J. Van Den Bosch and Henk W. Volberda,(2012). Management Innovation and Leadership: The Moderating Role of Organizational Size, Journal of Management Studies 49:30-31

İşcan, Ö. F. ve Timuroğlu, K. (2007). "Örgüt Kültürünün İş Tatmini Üzerindeki Etkisi ve Bir Uygulama”. Atatürk Üniversitesi Sosyal Bilimler Enstitüsü Dergisi, 21(1): 119-135.

Jones, R. A., Jimmieson, N. L. ve Griffiths, A. (2005). “The Impact of Organizational Culture and Reshaping Capabilities on Change Implementation Success: The Mediating Role of Readiness for Change". Journal of Management Studies, 42(2): 361-386.

Julia Nieves, Mercedes Segarra-Cipres. (2015). Management Innovation in Hotel İndustry, Journal of Tourism Management, 46 : 51-58

Keating, M., (2008). 'Culture and Social Science', in D. Della Porta ve M. Keating, eds., Approaches and Methodologies in the Social Science: A Pluralist perspective, Cambridge Universty Press, 99-117

Kırım, Arman, (2007). ‘Karlı Büyümenin Reçetesi İnovasyon', Sistem Yayincilik,Istanbul,Turkey 
Journal of Global Strategic Management | V. 12 | N. 2 | 2018-December| isma.info | 027-036 | DOI: 10.20460/JGSM.2019.266 Laverie, D. A., Madhavaram, S. and McDonald, R. E. (2008). Developing a Learning Orientation: The Role of Team Based ActiveLearning. Marketing Education Review, Vol.18, No.3, pp.37-51.

Leonard-Barton, Dororthy (1992). "Core Capabilities and Core Rigidities: a Paradox in Managing New Product Development”, Strategic Management Journal, Vol.13: 111-125.

Hatch M.J., and AL Cunliffe , (2006). Organization Theory: Modern, Symbolic and Postmodern Perspectives,(Oxford University Press)

Pettigrew, A. M., (1979). On Studying Organizational Cultures, Administrative Science Quarterly, 24: 570-581

Cooper, R.G. and Kleinschmidt, E.J., (1995). Benchmarking the Firm's Critical Success Factors in New Product development - Journal of Product Innovation Management, Vol:12.5: 374-391

Walker R. , Damanpour , F. ,Devece, C.,(2010). Management Innovation and Organizational Performance, Universty of Hong Kong, Journal of Public Administration Research and Theory, Vol:21: 367-385

Rosenau, M. D. and Moran J. J., (1993). Managing the Development of New Products: Achieving Speed and Quality Simultaneously through Multifunctional Teamwork, Van Nostrand Reinhold, New York.

Sanders, N. R. and Manrodt, K. B., (1994). "Forecasting Practices in US Corporations: Survey Results", Interfaces, 24 (2):92-100.

Schein E.H., (2010). Organizational Culture and Leadership, Jossey Bass, USA.

Elçi, Ş., (2007) Inovasyon Kalkınmanın ve Rekabetin Anahtarı, Ankara, Technopolis Group.

Trice, H. M., and Beyer, J. M., (1993). The cultures of work organizations. Englewood Cliffs, NJ, US: Prentice-Hall, Inc.

Trrot Paul, (2008), Innovation Management and New Product Development, 4th Edition, England: Prentice Hall.

Unutkan, G.A.(1995). İşletmelerde Yönetimi ve Örgüt Kültürü, Istanbul Türkmen Kitabevi, Istanbul.

Yang, J. and L. Yu (2002). "Electronic New Product Development: A Conceptual Framework”, Industrial Management and Data Systems, 102 (4):218-225.

Yonggui Wang ; Shanji Yao ; Zhu Sun ; He Jia, (2008). Meta Analysis of the Relationship between Product Innovation and Business Performance, 4th IEEE International Conference on Management of Innovation and Technology, China, 906-911. 